\title{
Erratum to: Metallic ion content and damage to the DNA in oral mucosa cells patients treated dental implants
}

Pía López-Jornet · Francisco Parra Perrez • José Luis Calvo-Guirado • Irene Ros-Llor • Piedad Ramírez-Fernández

Published online: 25 May 2014

(C) Springer Science+Business Media New York 2014

\section{Erratum to: J Mater Sci: Mater Med}

\section{DOI 10.1007/s10856-014-5203-7}

The original version of this article unfortunately contained a mistake. The authors omitted to note the co-author's name Irene Ros-Llor was incorrect. The authors apologise for this error and the inconvenience it has caused.

The online version of the original article can be found under doi:10.1007/s10856-014-5203-7.

P. López-Jornet · F. P. Perrez · I. Ros-Llor

Oral Medicine Department, Faculty of Medicine and Dentistry,

Ageing Research Institute, University of Murcia, Murcia, Spain

P. López-Jornet ( $₫)$

Clínica Odontológica Universitaria, Hospital Morales Meseguer,

Adv. Marques de los Velez s/n, 30008 Murcia, Spain

e-mail: majornet@um.es

J. L. Calvo-Guirado · P. Ramírez-Fernández

Department of Implant Dentistry, School of Medicine

and Dentistry, University of Murcia, Murcia, Spain 